\title{
Morphological Study of the Cytoplasmic Droplets as an Index of Sperm Maturation in Black Bengal Buck (Capra hircus)
}

\author{
Estudio Morfológico del Droplet Citoplasmático como un Índice de \\ Maduración de Espermatozoides en Cabras Black Bengal (Capra hircus)
}

"Uttam Datta; * Soumendra Kumar Bandopadhyay \& *** Manik Lal Hembram

DATTA, U.; BANDOPADHYAY, S. K. \& HEMBRAM, M. L. Morphological study of the cytoplasmic droplets as an index of sperm maturation in Black Bengal buck (Capra hircus). Int. J. Morphol., 28(1):327-332, 2010.

SUMMARY: Location of the cytoplasmic droplets $(C D)$ and their dimensions varied significantly $(\mathrm{p}<0.01)$ when sperm cells traverse through the regions of caput, corpus and cauda epididymis and vasdeferens respectively. The gradual diminution in the morphology of $C D$ between the epididymal regions were related significantly $(\mathrm{p}<0.01, \mathrm{p}<0.05)$. Caudal shift of the $\mathrm{CD}$, along with regression in size and finally their exclusion from the sperm cells reflected one of the most important events in the maturation process of male gametes in Black Bengal buck.

KEY WORDS: Black Bengal buck, epididymis, spermatozoa, cytoplasmic droplets.

\section{INTRODUCTION}

Post-testicular maturation of spermatozoa in the epididymal regions involves morphological, physiological, biophysical, biochemical and metabolic changes which collectively reflect the process of maturation required for acquiring the ability of spermatozoa to fertilize ovum (Glover, 1974). One of the most striking changes in spermatozoa during their maturation phases are migration (Robaire \& Hermo, 1988) and alteration in the shape and size of the $\mathrm{CD}$, the remnants of spermatid cytoplasm which appears on the sperm cells during the process of spermatogenesis and ultimately excludes from the lumen by epithelial phagocytosis (Cooper, 2005).

During spermatozoal transit through the excurrent ducts, CD migrates from it's proximal region to distal region (Jindal \& Panda, 1980; Rao et al., 1980; Awojobi \& Oyeyemi, 2001; Oyeyemi \& Ubiogoro, 2005), it's size varies from large elongated irregular bulbous structure to compact globular mass (Rao, 1958; Murphy et al., 1973), frequency of appearance decreases and ultimately lost (Rao et al.; Jindal \& Panda; Oyeyemi \& Ubiogoro; Cooper). These physiological changes are considered to be the most important index of sperm maturation (Bedford, 1963, 1966;
Guraya, 1987; Oyeyemi \& Ubiogoro; Cooper). It is postulated that presence of droplets in a significant number of ejaculates are considered as a sign of immaturity (Salisbury et al., 1978; Mann \& Lutwak-Mann, 1981) and sometimes of infertility (Bedford, 1975; Cooper).

Biometrical study of the CD has been reported in Plethodontid salamander spermatozoa (Murphy et al.), however, studies on the biometry of morphological changes in the CD during migration and / or maturation phases of spermatozoa in the excurrent duct have not been reported in any other animals so far. Hence, this study was aimed to observe the changes in dimensional characters of $\mathrm{CD}$ along with their migrational status during epididymal sojourn of spermatozoa in the Black Bengal buck.

\section{MATERIAL AND METHOD}

Forty-five adult and healthy Black Bengal bucks from goat breeding farm of the University were selected for the experimental purpose. Age and body weight of the animals

* Lecturer, Department of Veterinary Gynaecology \& Obstetrics, India.

** Former Professor, Department of Veterinary Gynaecology \& Obstetrics, India.

${ }^{* * *}$ Ph.D. Scholar, Department of Veterinary Gynaecology \& Obstetrics, India. 
were 3 to $31 / 2$ years and 12.5 to $14.5 \mathrm{Kg}$, respectively. All the animals were maintained on the standard balanced feed and water supplied ad libitum.

For the experiment, each buck was castrated by open method (O'Conner, 1980). Immediately after castration tunica albuginea was removed from both the testis. According to the anatomical positions, ligatures were placed unilaterally at the proximal end of the vasdeferens, ampullae and cauda epididymides separately and distal to caput epididymides and vasefferentia. After ligations, epididymides along with vasdeferenses were dissected out from each testis and washed thoroughly by normal saline solution. Each ligated portion of the excurrent duct was cut gently and kept into separate polystyrene Petri dishes containing $2 \mathrm{ml}$ of $0.15 \mathrm{M}$ phosphate buffer saline (PBS, $\mathrm{pH} 7.4$ ) at $37{ }^{\circ} \mathrm{C}$. The individual portions were minced carefully and luminal content form each portion was collected by giving gentle pressure on the excised tissues into the medium with separate clean glass rods. The resultant suspensions were filtered through individual nitex membrane (150 $\mathrm{mm}$ pore size) to free the cellular debris. Each filtrate was collected into separate glass test tubes, centrifuged at $500 \mathrm{~g}$ for $10 \mathrm{~min}$ and the supernatants were discarded. Finally, $200 \mathrm{ml}$ of PBS was added to each sperm pellet separately, vortexed for $3 \mathrm{~s}$ and kept at $370 \mathrm{C}$ into an incubator provided with $5 \% \mathrm{CO}_{2}$ in air for $15 \mathrm{~min}$.

To observe the different migrational positions of the $\mathrm{CD}$ on the sperm cells, smears were prepared on the microscopic glass slides from sperm suspensions prepared from different segments and stained with Eosin-Nigrosin stain (Hancock, 1951). Total 100 spermatozoa from each coded slide of 45 bucks were counted at random under the light microscope (x 400, x 1000) in order to locate the position of the migrational changes of $\mathrm{CD}$ and the mean results were finally converted to arcsin value.

To measure the $\mathrm{CD}, 10 \mathrm{ml}$ of the sperm suspension from each epididymal region of each buck was placed on the microscopic glass slides pretreated with $70 \%$ alcohol. Uniform smears were drawn and air-dried. Smears were fixed into methanol for $10 \mathrm{~min}$ and stained with Giemsa stain, for $1 \mathrm{~h}$ at $37^{\circ} \mathrm{C}$ in humid condition. The smears were washed with PBS followed by in distilled water. Smears were air dried, mounted with DPX and coded properly. Measurements of the droplets were made with Leitz ocular micrometer under the microscope (x 1000) by counting 50 normal spermatozoa from each coded slide. Approximately two longest axis each for length and breadth were measured. Mean values were analyzed statistically (Snedecor \& Cochran, 1967).

\section{RESULTS}

Table I depict different positions of the $\mathrm{CD}$ on the sperm cells from the three epididymal regions and vasdeferens respectively. Higher percentages of anterior droplets in caput and corpus epididymis were observed when compared with the spermatozoa from the caudal epididymis and from vasdeferens.

The variations in the different locations of $\mathrm{CD}$ on the sperm cells were found highly significant $(\mathrm{p}<0.01)$ between caput vs corpus; corpus vs cauda and vasdeferens, and cauda vs vasdeferens respectively (Table II). A large number of droplets from the caudal regions were found sloughing off from the sperm cells in the microscopic fields during preparation of the smears (Fig. 1).

The dimensional characters of $\mathrm{CD}$ from the caput, corpus and cauda epididymal regions were $2.88 \pm 0.33,2.47$ \pm 0.02 and $2.19 \pm 0.01 \mathrm{~mm}$, respectively in length and 2.34 $\pm 0.05,2.04 \pm 0.03$ and $1.59 \pm 0.07 \mathrm{~mm}$, respectively in breadth. Observations revealed (Table III) that length and breadth of $C D$ varied significantly $(p<0.01)$ between caput vs corpus and cauda; and corpus vs cauda. However, the breadth when compared in between corpus and caudal region it was found less significant $(\mathrm{p}<0.05)$.

The regression of each dimensional character in different epididymal regions revealed that positive and highly significant relationship $(\mathrm{p}<0.01)$ existed in length of the $C D$ between caput vs corpus $(\mathrm{r}=0.50)$. However, negative relationships were found in caput vs cauda $(r=-0.19)$ and corpus vs cauda $(r=-0.004)$. Similar significant $(p<0.01)$ relationship in breadth of the $\mathrm{CD}$ between caput vs corpus $(r=0.59)$ and negative relationship between caput vs cauda $(\mathrm{r}=-0.16)$ were also found. However, positive relationship $(\mathrm{r}=0.15)$ between corpus vs cauda in breadth was also existed (Table IV). These relationships reflected the biometrical reduction of CD that occurred in corpus, moreover, caudal regressions were more predominant than in caput.

\section{DISCUSSION}

The possible physiological significance of $\mathrm{CD}$, the un-sequestered cytoplasm, in relation to sperm metabolism and maturation are still to be investigated. However, the movement, alteration in the fine structure and position of the $\mathrm{CD}$ during spermatozoan passage through the epididymis plays a key role for maturation of the male gametes. It is 
Table I. Location of the CD on the spermatozoa from the different epididymal regions and vasdeferens of Black Bengal bucks.

\begin{tabular}{|c|c|c|c|c|c|c|c|c|c|}
\hline \multicolumn{10}{|c|}{ Locations of the CD (\%) } \\
\hline $\mathrm{N}^{\circ} \mathrm{Ob}$ & Regions & $\mathrm{CSN}$ & SAN & AEM & MM & PEM & MT & TT & $\mathrm{A}$ \\
\hline 45 & Caput & $52.86 \pm 4.33$ & $38.96 \pm 4.63$ & $8.1 \pm 1.64$ & - & - & - & - & - \\
\hline 45 & Corpus & $3.73 \pm 0.68$ & $6.2 \pm 1.07$ & $28.8 \pm 0.89$ & $24.63 \pm 1.24$ & $24.63 \pm 1.24$ & $37.96 \pm 1.99$ & - & - \\
\hline 45 & Vas deferens & - & - & - & - & - & $1.23 \pm 10.39$ & $0.33 \pm 0.28$ & $4.73 \pm 0.4$ \\
\hline
\end{tabular}

$\mathrm{NOB}=$ Number of observations; Values expressed as Mean \pm SE; \% location transformed into arcsin $\sqrt{ }$--Percentage.

CSN:Completely surrounding the neck; SAN:Slightly away from the neck; AEM: Anterior end of the midpiece; MM:Middle of the midpiece; PEM:Posterior end of the midpiece; MT:Middle of the tail; TT:Tip of the tail; A:Absent.

Table II. 't' (paired) values showing variations in the location of cytoplasmic droplets on the sperm cells from different epididymal regions and vasdeferens.

\begin{tabular}{|c|c|c|c|c|c|c|c|c|}
\hline \multicolumn{9}{|c|}{ Location of the cytoplasmic droplets } \\
\hline \multirow{2}{*}{ Region } & \multicolumn{3}{|c|}{ Corpus } & \multirow{2}{*}{$\begin{array}{c}\text { Corpus } \\
\text { PEM }\end{array}$} & \multirow{2}{*}{$\begin{array}{l}\text { Cauda } \\
\text { PEM }\end{array}$} & \multicolumn{3}{|c|}{ Vas deferens } \\
\hline & $\mathrm{CSN}$ & SAN & AEM & & & MT & TT & A \\
\hline Caput & $14.42 * *$ & $7.78 * *$ & $7.74 * *$ & & & & & \\
\hline Corpus & & & & & & & & \\
\hline Cauda & & & & $13.19 * *$ & & $2.66^{\mathrm{NS}}$ & $1.11^{* *}$ & $28.32 * *$ \\
\hline Vas deferens & & & & $23.02 * *$ & $35.31 * *$ & & & \\
\hline
\end{tabular}

Degree of freedom $=44 ; \quad * *=$ significant at $1 \%$ level; $\quad \mathrm{NS}=$ non-significant

CSN:Completely surrounding the neck; SAN:Slightly away from the neck; AEM:Anterior end of the midpiece; PEM:Posterior end of the midpiece; MT: Middle of the tail; TT:Tip of the tail; A:Absent.

Table III. ' $t$ ' values showing variations in the dimensional characters of the cytoplasmic droplets from different epididymal regions.

\begin{tabular}{lcccc}
\hline & \multicolumn{3}{c}{ Cytoplasmic droplets } & Breadth \\
\cline { 2 - 5 } Region & Corpus & Cauda & Corpus & Cauda \\
\hline Caput & $5.89^{* *}$ & $7.41^{* *}$ & $2.99^{* *}$ & $3.14^{* *}$ \\
Corpus & & $4.18^{* *}$ & & $2.36^{*}$ \\
\hline
\end{tabular}

Degree of freedom $=44 ; \quad * *=$ significant at $1 \%$ level; $\quad *=$ significant at $5 \%$ level

Table IV: Correlation of different dimensional characters of the cytoplasmic droplets from different epididymal regions.

\begin{tabular}{|c|c|c|c|c|c|}
\hline \multirow{3}{*}{$\mathrm{N}^{0}$ observations } & \multicolumn{3}{|c|}{ Cytoplasmic droplets } & \multirow{2}{*}{\multicolumn{2}{|c|}{ Breadth }} \\
\hline & Regions & & & & \\
\hline & & Corpus & Cauda & Corpus & Cauda \\
\hline 45 & Caput & $0.50 * *$ & -0.19 & $0.59 * *$ & -0.16 \\
\hline 45 & Corpus & & 0.004 & & 0.15 \\
\hline
\end{tabular}

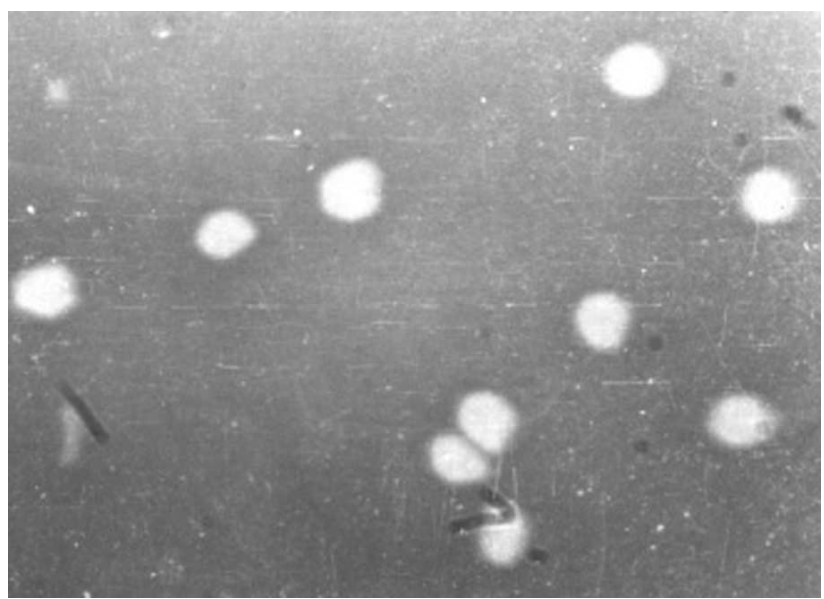

Fig. 1. Photomicrograph of excluded cytoplasmic droplets from the sperm cells of caudal regions $(\mathrm{x}$ 1000). 
assumed that the droplets may have a nutritive role in theeconomy of the spermatozoon and may be the source of metabolizable endogenous substrate (Guraya). The lysosomal enzymes of the droplets perhaps prepare the spermatozoon for the final stage of its maturation (Mann, 1975; Cunningham \& Hafez, 1980). Another plausible importance that through CD osmolytes and water passes to sperm cells for maintaining volume regulation of spermatozoa (Barfield, 2005; Yeung et al., 2005). Moreover, presence of $\mathrm{CD}$ on the sperm cells is believed to be involved in the regulation of cycle of seminiferous epithelium (Mann \& Lutwak-Mann).

Presence of CD, on the sperm cells observed in Black Bengal buck, their migration from proximal region to distal region of the spermatozoa, moreover, decrease in their number and/or absence during passage through the male tracts- as a sequence of sperm maturation corroborated with the findings obtained from different mammalian species by Bedford (1963, 1966), Kilicoglu (1978), Salisbury et al., Jindal \& Panda, Oyeyemi \& Ubiogoro. Our experiment also supports the observations of Awojobi \& Oyeyemi and Anand \& Atreja (1986) that most of the spermatozoa from corpus, cauda epididymis and vasdeferens possess distal droplets and spermatozoa from cauda and vasdeferens had less number of $\mathrm{CD}$.

Present observation also revealed that droplets surrounding the neck of the spermatozoa in the caput region were irregular in shape and were larger than those found in other regions of the epididymis where they were mostly compact, globular and smaller in size. These findings was synonymous with the observations in farm animals (Mukherjee \& Bhattacharjee, 1949; Rao; Bedford, 1963,
1966; Rao et al.; Guraya) and in Plethodontid salamander spermatozoa by Murphy et al. who also reported that the length of the CD of salamander spermatozoa varied from 30 $\mu \mathrm{m}$ to $11 \mu \mathrm{m}$. Present observation also simulate with the view of Flechon \& Hafez (1975) that the CD regresses and moves towards the posterior end of the middle piece during their transport in the epididymis.

It is assumed that the event of gradual reduction in the shape and size of the CD plausibly were accompanied by dehydration of the vesicle which is surrounded by plasmalemma that resulted in ultrastructural changes of the droplets (Nicander, 1957; Orgebin-Crist, 1967; Hamilton, 1972).

CD which sloughed off from the sperm cells as found from the caudal smear, plausibly indicates a physiological relation with the motility of spermatozoa and their metabolism, because rapid forward progression appears first in the middle of the corpus in few number of spermatozoa and becomes the predominating motility pattern in the cauda and vasdeferens. Moreover, presence of spermatid cytoplasm is thought to be important for sperm maturation by playing its role in inositol synthesis and metabolism of spermatozoa (Roberts et al., 1976), and regional alterations in the ionic composition of the epididymal fluids (Howards et al., 1979) are believed to be responsible for distal movement and ultimate loss of the droplet (Bedford 1975, 1979).

Migrational changes of the spermatid cytoplasm, deviation in their shape and size and ultimately exclusion from the sperm cells emphasized that spermatozoa in the Black Bengal buck also pass through a maturational phase prior to their ejaculation as found in other mammalian species.

DATTA, U.; BANDOPADHYAY, S. K. \& HEMBRAM, M. L. Estudio morfológico del droplet citoplasmático como un índice de maduración de espermatozoides en cabras Black Bengal (Capra hircus). Int. J. Morphol., 28(1):327-332, 2010.

RESUMEN: La ubicación de los droplets citoplásmicos (CD) y sus dimensiones variaron significativamente $(\mathrm{p}<0,01)$ cuando las células espermáticas atraviesan a través de las regiones de cabeza, cuerpo y cola de epidídimo y vas deferens respectivamente. La disminución gradual en la morfología de los $\mathrm{CD}$ entre las regiones del epidídimo se relacionaron de forma significativa ( $\mathrm{p}<0,01, \mathrm{p}$ $<0,05)$. El desplazamiento caudal de las CD, junto con la regresión en el tamaño y, finalmente, su exclusión desde los espermatozoides refleja uno de los eventos más importantes en el proceso de maduración de los gametos masculinos en la cabra Black Bengal.

PALABRAS CLAVE: Cabra Black Bengal; Epidídimo; Espermatozoide; Droplets citoplasmáticos.

\section{REFERENCES}

Anand, S. R. \& Atreja, S. K. Lipids in goat cytoplasmic droplets and spermatozoa in transit from the caput to cauda epididymis. Ind. J. Biochem. and Biophysics, 23:258-65, 1986.
Awojobi, H. A. \& Oyeyemi, M. O. Morphological changes in epididymal spermatozoa of Red Sokoto (maradi) bucks. Nigerian J. Anim. Prod., 28(2):207-10, 2001. 
Barfield, J. P.; Yeung, C. H. \& Cooper, T. G. Characterization of potassium channels involved in volume regulation of human spermatozoa. Mol. Hum. Reprod., 11:891-7, 2005.

Bedford, J. M. Changes in the electrophoretic properties of rabbit spermatozoa during passage through the epididymis. Nature, 200:1178-80, 1963.

Bedford, J. M. Development of the fertilizing ability of spermatozoa in the epididymis of rabbit. J. Exp. Biol., 163:319-30, 1966.

Bedford, J. M. In: The spermatozoon. Eds. Fawcett, D. W. \& Bedford, J. M. Baltimore, Urban \& Schwarzenberg, 1979. pp.7-21.

Bedford, J. M. Maturation, transport \& fate of spermatozoa in the epididymis. In: Handbook of physiology, Vol. V. (Eds) Hamilton, D. W. \& Greep, R. Washington, American Physiological Society, 1975. pp.307-17.

Cooper, T. G. Cytoplasmic droplets: the good, the bad or just confusing? Human. Reprod., 20:9-11, 2005.

Cunningham, G. R \& Hafez, E. S. E. In: Regulation of male fertility. Boston, Martinus Nijhoff Publications, 1980.

Flechon, J. E. \& Hafez, E. S. Spermiation and epididymal maturation of spermatozoa in the bonnet macaque (Macaca radiata) as viewed by Scanning Electron Microscopy. Fertil. Steril., 26:1219-27, 1975.

Glover, T. D. Recent progress in the study of male reproductive physiology; testis stimulation, sperm formation, transport and maturation (epididymal physiology); semen analysis, storage and A.I. In: MTP International Review of Science. Series I. Vol. 8. Reproductive Physiology. London, Butterworths, 1974. pp.221-76.

Guraya, S. S. Biology of spermatogenesis and spermatozoa in mammals. Heidelberg, Spinger-Verlag, 1987.

Hamilton, D. W. The mammalian epididymis, Reproductive Biology. Amsterdam, Excerpta Medica, 1972. pp.269337.

Hancock, J. L. A staining technique for the study of temperature shock in semen. Nature, 167:323, 1951.

Howards, S.; Lechee, C. \& Vigersky, R. In: The spermatozoon. Fawcett, D. W. \& Bedford, J. M. (Ed).
Baltimore, Urban and Schwarzenberg, 1979. pp.35-41.

Jindal, S. K. \& Panda, J. N. Epididymal sperm reserves of the goat. J. Reprod. Fertil., 59(2):469-71, 1980.

Kilicoglu, C. Effects of seminal vesicle secretion on cytoplasmic droplets of epididymal spermatozoa obtained from local bulls. Ankara Üniv. Vet. Fak. Derg., 25(3):432-47, 1978.

Mann, T. Biochemistry of semen. In: Greep, R. O. \& Astwood, E. B. (eds) Handbook of physiology. Washington, American Physiol. Soc., 1975. p.461.

Mann, T. \& Lutwak-Mann, C. Male reproductive function and semen. Berlin, Spinger- Verlag, 1981.

Mukherjee, D. P. \& Bhattacharjee, P. Study of spermatozoa from different levels of the male reproductive tracts of the sheep, goat and buffalo. Proceedings of the Zoological society of Bengal, 2:149-61, 1949.

Murphy, J. A.; Wortham, J. W. E.; Marton, J. \& Thompson, N. R. Morphological aspects of cytoplasmic droplets of some plethodontid salamander spermatozoa. J. Reprod. Fertil., 35:377-80, 1973.

Nicander, L. On the regional histology and cytochemistry of the ductus epididymidis in rabbits. Acta Morphol. Neerl. Scand., 1(2):99-118, 1957.

O'Conner, J. J. Dollars Veterinary Surgery. $4^{\text {th }}$ Ed. Delhi, CBS Publishers and distributions, 1980.

Orgebin-Crist, M. C. Maturation of spermatozoa in the rabbit epididymis, fertilizing ability and embryonic mortality in does inseminated with epididymal spermatozoa. Anns. Biol. Anim. Biochim. Biophys., 7:373-89, 1967.

Oyeyemi, M. O. \& Ubiogoro, O. Spermeogram and morphological characteristics in testicular and epididymal spermatozoa of large white boar in Nigeria. Int. J. morphol., 23(3):235-9, 2005.

Rao, A. R.; Bane, A. \& Gustafsson, B. K. Changes in the morphology of the spermatozoa during their passage through the genital tract in dairy bulls with normal and impaired spermatogenesis. Theriogenology, 14(1):1-12. 1980.

Rao, C. K. Study on morphology and development of spermatozoa of farm animals. Indian Vet. J., 53:268-80, 1958. 
DATTA, U.; BANDOPADHYAY, S. K. \& HEMBRAM, M. L. Morphological study of the cytoplasmic droplets as an index of sperm maturation in Black Bengal buck (Capra hircus). Int. J. Morphol., 28(1):327-332, 2010

Robaire, B. \& Hermo, L. Efferent ducts epididymis and vasdeferens: Structure, function and their regulation. In: Knobil, E. \& Neill, J. (Eds.) The Physiology of reproduction. New York, Raven Press Ltd., 1988. pp.9991080.

Roberts, M. L.; Scouten, W. H. \& Nyquist, S. E. Isolation and characterization of cytoplasmic droplets in the rat. Biol. Reprod., 14(4):421-4, 1976.

Salisbury, G. W.; Vandemark, N. L. \& Lodge. Physiology of Reproduction and Artificial Insemination of cattle. $2^{\text {nd }}$ edn. San Fransisco, W. H. Freeman and Co., 1978.

Snedecor, G. W. \& Cochran W.G. Statistical methods. $6^{\text {th }}$ Edn. Ames, The Iwoa State University Press, 1967.

Yeung, C. H.; Barfield, J. P. \& Cooper, T. G. Chloride channels in physiological volume regulation of human spermatozoa. Biol. Reprod., 73:1057-63, 2005.
Correspondence to:

Dr. Uttam Datta, M.V.SC, Ph.D.

Senior Lecturer

Department of Veterinary Gynaecology \& Obstetrics Faculty of Veterinary and Animal Science 37and 68, Kshudiram Bose Sarabi

Belgachi, Kolkata -700037

West Bengal

INDIA.

Phone (+91) 9830662044

Email: uttamdtt@yahoo.com

Received: 16-02-2009

Accepted: 21-11-2009 